\title{
The Testimony of Moses in the Fourth Gospel: Beyond the Passover Feast, and into the Wilderness
}

\author{
James R. Page, S.J. \\ Boston College School of Theology and Ministry (Brigton, MA)
}

\section{Introduction: Beyond the Passover Feast}

Traditional exegesis on the Fourth Gospel takes a rather dim view of 'the Jews' who appear within the text's narrative. These traditional claims often charge that the reason Jews were unable to receive Christ's Gospel was because they were overly attached to Moses. ${ }^{1}$ In this paper, I will argue that anti-Jewish claims of this sort cut against the grain of the Fourth Gospel itself, where Jesus is repeatedly depicted as stressing his continuity, rather than disjunction, with Torah. Indeed, Jesus at one point fully acknowledges that "if you do not trust what [Moses] wrote, how will you trust what I say?" (John 5:47) Far from an exhortation to abandon Moses, Jesus readily admits that his teachings rely on the testimony of Moses. In order to illustrate the intimate connection that the Fourth Gospel has to its Jewish context, I will begin by offering a review of the Fourth Gospel's unique manner of using Old Testament texts, and then examine how this particularly Johannine vision of intertextuality is deployed in framing the Eucharistic Discourse (Jn 6:25-71) around the experience of the ancestral journey through the wilderness as recorded in Numbers: the gift of manna to the hungry travelers, the grumbling of these same travelers against the authority of their

\footnotetext{
${ }^{1}$ Just as one example among many, when John Chrysostom assesses why the Jewish multitudes ultimately reject Jesus in the Eucharistic Discourse (6:25-71), he claims that it is because of their unreasonable attachment to the authority of Moses (John Chrysostom, Commentary on Saint John the Apostle and Evangelist, Homilies 1-47, trans. Sister Thomas Aquinas Goggin, The Fathers of the Church Series, vol. 33 [Washington, DC: The Catholic University of America Press, 1969], p. 451). When confronted with 'this hard teaching' (Jn 6:60) from the Eucharistic Discourse, Chrysostom concludes that: "The scandal, then, consisted in their [the Jews'] perversity, not in the doubtful meaning of His words" (Chrysostom, Commentary on John, p. 466). Admittedly, even among patristic writers, Chrysostom is particularly noteworthy for his virulent anti-Jewish rhetoric.
} 


\section{PAGE: THE TESTIMONY OF MOSES IN THE FOURTH GOSPEL}

teacher, and the fate of the ancestors in the wilderness. ${ }^{2}$ By framing the eucharistic encounter with the episode of the manna consumed during the ancestral wilderness journey, the Fourth Gospel is no longer depicting Jesus as a Passover lamb that the people offer to propitiate the Divine, but as a gift from the Divine to the people, bringing Life into the world.

In the spirit of Nostra aetate, I propose that an exegesis of this passage within these parameters opens up the possibility of fruitful inter-religious dialogue. Are we as a Church courageous enough to enter into dialogue with religious alterity, and give our partners in dialogue the dignity of listening to their critiques? How do we as a Church respond to the voice of critique, and correspondingly, how could we grow from it? Hearkening to the response of Jesus's Jewish interlocutors in the Fourth Gospel's Eucharistic Discourse offers today's Catholics the possibility of approaching the eucharistic feast in a new way, free from anti-Jewish underpinnings, and with a greater degree of continuity with our Old Testament heritage.

\section{Intertextuality in the Fourth Gospel: A Unique Idiom}

Each of the four canonical Gospels has its own unique manner of using the Old Testament. ${ }^{3}$ For the particular section of the Fourth Gospel that will be analyzed in this paper, the Eucharistic Discourse, the evangelist made extensive use of wilderness and prophetic imagery in framing its narrative. However, the Fourth Gospel's distinctive method of intertextuality, its unique manner of communicating the Christian message, also serves to communicate its own understanding of that message. Much of this literary artistry, however, can end up being lost to the modern reader,

\footnotetext{
2 There is no general agreement about where precisely the Eucharistic Discourse begins in the sixth chapter of the Fourth Gospel. The setting for the discourse, however, is clearly stated: "He said these things while he was teaching in the synagogue at Capernaum" (Jn 6:59). Therefore, the present article will set as the beginning of the Eucharistic Discourse the verse where the reader is informed that the multitudes have arrived in Capernaum (cf. Jn 6:24-25). 14.

${ }^{3}$ cf. Richard Hays, Echoes of Scripture in the Gospels (Waco, TX: Baylor University Press, 2016), pp. 13-
} 


\section{PAGE: THE TESTIMONY OF MOSES IN THE FOURTH GOSPEL}

who more often than not approaches the Fourth Gospel with the aim of harmonizing its account with that of the Synoptics. Though certainly still within the stream of Christian tradition, the distinctiveness of the Fourth Gospel's literary achievement, and the originality of its message, should be classed alongside that of Saint Paul of Tarsus. ${ }^{4}$ The Fourth Gospel's literary distinctiveness is not restricted merely to the level of narrative content, comparing which stories appear in the Synoptics and which stories appear in the Fourth Gospel. Rather, the distinctiveness of the Fourth Gospel is most noteworthy when examining the manner in which the story of Jesus is told, related as it is within a uniquely Johannine idiom. If the Synoptic Gospels' rhetorical stress highlights the kingdom of God, and if Paul's epistles highlight the life of the Church, then it is the Fourth Gospel that highlights the new and eternal life that people now share with Jesus: "I came that they may have life, and have it abundantly" (John 10:10). ${ }^{5}$

Repeatedly throughout the Fourth Gospel's narrative, then, the case is being made for this unique idiom, this unique vision of intertextuality with the Old Testament, and an early pericope

${ }^{4}$ This present work will limit itself to examining the literary connections that can be fruitfully discerned between the Fourth Gospel and its Old Testament intertextual referents. Discussions concerning the origins of the Fourth Gospel, or the community from whence it sprung, will be bracketed, not only for the sake of brevity, but in order to focus the discussion on the Fourth Gospel as a final work of literature. The argument in this article does not rely on conjectural reconstructions of community identity, nor does it posit any particular origin for the writing of the Fourth Gospel, apart from its composition in the aftermath of the Second Temple Period, and its indebtedness to apocalyptic (cf. John Ashton, "Intimations of Apocalyptic" in Understanding the Fourth Gospel [Oxford, UK: Clarendon Press, 1991], pp. 383-406; Catrin H. Williams and Christopher Rowland, eds., John's Gospel and Intimations of Apocalyptic [New York, NY: Bloomsbury T\&T Clark, 2013]; Frederick J. Murphy, "The Gospel of John" in Apocalypticism in the Bible and Its World [Grand Rapids, MI: Baker Academic, 2012], pp. 275-278). Though the search for the origin(s) of the Johannine community has been a notably difficult academic enterprise and the scholarly inquiries into this question can seem alternatively enigmatic, baffling, or inconclusive, noteworthy ventures into this field include the work of Raymond Brown (The Community of the Beloved Disciple [Mahwah, NJ: Paulist Press, 1979]), though more recently the contributions of James Charlesworth have been very intriguing ("Part One: Origin, Evolution, and Settings of the Gospel of John" in Jesus as Mirrored in John: The Genius of the New Testament [New York, NY: T\&T Clark, 2019], pp. 19-127). For a fantastic review of scholarship on the Johannine community, including some important considerations that raise some doubts about the future of this line of inquiry, see: Robert Kysar, "The Whence and Whither of the Johannine Community," in Life in Abundance: Studies of John's Gospel in Tribute to Raymond E. Brown, ed. John R. Donahue (Collegeville, MN: Liturgical Press, 2005), pp. 65-90 (which also includes a response by Hans-Josef Klauck, O.F.M.).

${ }^{5}$ The writer of the Fourth Gospel will later explicitly state this as the principal foundation of this work, if not its very purpose: "But these are written so that you may come to believe that Jesus is the Messiah, the Son of God, and that through believing you may have life in his name" (20:31). 


\section{PAGE: THE TESTIMONY OF MOSES IN THE FOURTH GOSPEL}

in the Fourth Gospel's narrative serves admirably as an illustration for this dynamic: the dialogue between Nathanael and Philip concerning the testimony of Moses (Jn 1:45-46). Towards the beginning of the Fourth Gospel, the story is told of Philip going out to meet Nathanael in order to announce the good news about Jesus, and the manner in which Philip proclaims Jesus's identity to Nathanael is telling: "We have found the one about whom Moses wrote in the law, and also the prophets: Jesus, the son of Joseph from Nazareth" (1:45). In this one sentence Philip makes a spectacularly bold claim, that the figure attested to by Moses and the prophets has not only been revealed, ${ }^{6}$ but is now present among the people of Israel. In support of this claim, Philip does not provide any citations from Scripture, nor does he quote from any texts, when making this proclamation. Why is it, then, that the Fourth Gospel has Philip: (1) make the claim that Moses attested to Jesus, but (2) not quote Torah in support of this claim? Whatever the answer to this question, it is noteworthy that this reluctance on Philip's part in the narrative, to explicitly cite passages from the Old Testament, is likewise found in the evangelist's own style of writing.

One of the most distinctive features of the Fourth Gospel is how reluctant the evangelist is to explicitly cite Old Testament passages. One phrase that had come to be employed for the purpose of citation, "as it is written," is rarely encountered when reading through the Fourth Gospel, occurring only twice $(6: 31 ; 12: 14)$, and never on the lips of Jesus. ${ }^{7}$ Of the four canonical Gospels, the Fourth Gospel is the least likely to make these kinds of explicit references, ${ }^{8}$ preferring

\footnotetext{
${ }^{6}$ Though, of course, one must bear in mind that Moses is considered the foremost among the prophets (cf. Deut 18:15-18; Jn 6:14; 12:49).

7 The phrase 'as it is written' is a commonly deployed rhetorical device for proof-texting, indicating a reference to an authoritative text when making an argument or a particular point: Mt 26:24; Mk 1:2; 7:6; 9:13; 14:21; Lk 2:23; 3:4; Acts 7:42; 15:15; Rom 1:17; 2:24; 3:4, 10; 4:17; 8:36; 9:13, 33; 10:15; 11:8, 26; 15:3, 9, 21; 1 Cor 1:31; 2:9; 10:7; 2 Cor 8:15; 9:9; Gal 3:10 (see also: Lk 18:31; 24:44; Jn 2:17; 6:45; 10:34; 12:16; 15:25; Acts 24:14; 1 Cor

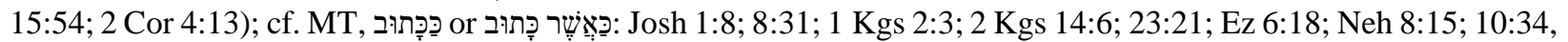

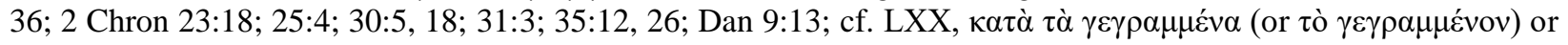

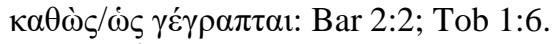

${ }_{8}^{8}$ According to Hays, Matthew makes 124 references to the Old Testament; Mark, 70; Luke, 109; and least of all, the Fourth Gospel, with 27 (Hays, Echoes in the Gospels, p. 283). Without worrying at this point about the
} 


\section{PAGE: THE TESTIMONY OF MOSES IN THE FOURTH GOSPEL}

instead to make connections to the Old Testament through literary allusions. ${ }^{9}$ The narrative within the Fourth Gospel becomes a kind of literary echo, resonant with the imagery and moral framing of its Old Testament background. Indeed, what the reader finds is that this literary or narrative preference for intertextuality is mirrored in Philip's own response to Nathanael's incredulity. When Nathanael expresses his doubts concerning Philip's claim, rather than responding with citations from the Old Testament to address Nathanael's concerns, Philip tells Nathanael quite simply to "come and see" (1:46). The invitation that Philip extends to Nathanael, to witness the life of Jesus, ${ }^{10}$ interpellates the reader of the Fourth Gospel, who has now become a kind of literary Nathanael, accompanying Jesus along his journey.

And how does the gospel narrative introduce the reader to the testimony of Moses? As it turns out, quite early on in the Fourth Gospel. This verse sets the tone for Torah's reception throughout the entire gospel account: "For the law was given through Moses, grace and truth came through Jesus Christ" (1:17). Whereas a number of traditional commentators have interpreted this early verse from the Fourth Gospel as a disjunctive, as though the contention were that the 'grace

precise number of references found in each Gospel to the Old Testament (itself a much disputed question, to be sure), this rough estimate at the very least provides a sense of the proportion of the difference between the canonical Gospels on how frequently they reference the Old Testament.

${ }^{9}$ Though there is obviously disagreement about precisely how many references the Fourth Gospel makes to the Old Testament, a conceptual distinction can be made at the outset between those passages that explicitly quote an Old Testament text, and those passages that deploy implicit references or literary allusions to Old Testament content. The Fourth Gospel clearly includes far fewer explicit quotations of the Old Testament than do the Synoptics, preferring instead to make literary allusions to the Old Testament. Menken notes 17 marked quotations to the Old Testament in the Fourth Gospel (cf. Maarten J. J. Menken, "Old Testament Quotations in the Gospel of John," in New Testament Writers and the Old Testament [London, UK: SPCK, 2002], p. 30). In Hays's work on Gospel intertextuality with the Old Testament, he points to 27 Old Testament references in the Fourth Gospel, a number he cites from the work of C.K. Barrett, who himself cited an appendix of Westcott and Hort's edition of the New Testament (cf. Hays, Echoes in the Gospels, p. 283; Charles K. Barrett, "The Old Testament in the Fourth Gospel," Journal of Theological Studies 48, 191/192 [July/October 1947], p. 155; Brooke F. Westcott and Fenton J.A. Hort, The New Testament in the Original Greek [London, UK: Macmillan, 1914], p. 605), where 21 verses in the Fourth Gospel are listed as referencing the Old Testament. Menken's 17 marked citations are a better gauge for instances wherein the Fourth Gospel explicitly quoted the Old Testament. Westcott and Hort failed to note many of the implicit references the Fourth Gospel made to the Old Testament (cf. Andreas J. Köstenberger, "John," in Commentary on the New Testament Use of the Old Testament, eds. Gregory K. Beale and Donald A. Carson [Grand Rapids, MI: BakerAcademic, 2007], pp. 419-420).

${ }^{10}$ Such that the life of Jesus itself becomes, in a sense, the testimony of Moses. 


\section{PAGE: THE TESTIMONY OF MOSES IN THE FOURTH GOSPEL}

and truth' of Christ now does away with the law of Moses, ${ }^{11}$ the narrative of the Fourth Gospel repeatedly reveals to the reader that the sense of this verse should be taken as a conjunctive:

"You search the Scriptures because you think that in them you have eternal life; and it is they that testify on my behalf. Yet you refuse to come to me to have life... If you trusted Moses, you would trust me, for he wrote about me. But if you do not trust what he wrote, how will you trust what I say?" (5:39-40a, 4647)

It is the gospel narrative itself that continually reiterates the claim that Moses testifies to Jesus. That is, that the law that came through Moses is not only in continuity with the grace and truth of Christ, but indeed that the law of Moses testifies to the grace and truth of Jesus Christ. Those commentators who are so intent on delegitimizing the testimony of Moses ultimately fail to recognize that the Fourth Gospel itself depicts Jesus as consistently claiming that his teachings rely on the legitimacy of Moses's testimony.

\section{Literary Framing: The Serpent in the Wilderness}

The legitimacy of Moses's testimony, as part of the arc of the Fourth Gospel's intertextual framework, is so important that before moving into the Eucharistic Discourse, there is one verse in the Fourth Gospel that must be covered, that perfectly illustrates the evangelist's: (1) reluctance to explicitly quote passages from the Old Testament, (2) conviction that Moses testifies to Jesus, and (3) deployment of wilderness literary framing, a narrative framework of particular significance to the Eucharistic Discourse:

Just as Moses lifted up the serpent in the wilderness, so must the Son of Man be lifted up, that whoever believes in him may have eternal life (3:14).

${ }^{11}$ Bultmann, for instance, explicitly refers to Jn 1:17 as an antithesis; cf. Rudolph K. Bultmann, The Gospel of John: A Commentary, trans. George R. Beasley-Murray, Rupert W.N. Hoare, and John K. Riches (Philadelphia, PA: Westminster Press, 1971), p. 79, n. 1. 


\section{PAGE: THE TESTIMONY OF MOSES IN THE FOURTH GOSPEL}

Note how this single verse in the Fourth Gospel contains no explicit quotation of an Old Testament passage. Neither is this verse saturated with exactly the same Greek words or structure from its referent passage in Numbers (Num 21:7-9). The only lexical markers tying these two passages

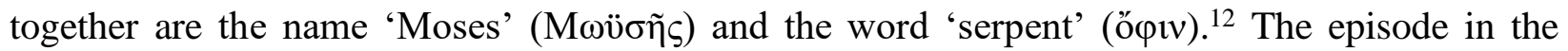
wilderness journey where Moses places a bronze serpent upon a pole, so that everyone who was bitten by a serpent could look upon it and live (Num 21:9) is paralleled in the Fourth Gospel's very next verse, with an exhortation that trust in Jesus bestows life (Jn 3:15). For the Fourth Gospel's evangelist, it is not only the content of Moses's message, but the example of his life that provides testimony to Jesus. Just as earlier on in the Fourth Gospel Philip claims that the life of Jesus will live out the testimony of Moses, so the reader repeatedly finds that the Fourth Gospel's allusions to the Old Testament are not typically made at the level of explicit quotations. Rather, the Fourth Gospel's allusions function at the level of imagery, promising continuity with the traditional stories of the people's ancestors. ${ }^{13}$

\footnotetext{
${ }^{12}$ Interestingly, the LXX depicts Moses as having made the serpent, and then making it stand "upon a sign"

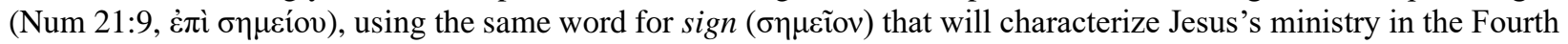
Gospel.

${ }^{13}$ The manner in which I have characterized the Old Testament intertextual references in the Fourth Gospel is particularly relevant to the first section of the Fourth Gospel, classically referred to as the Book of Signs (1:1912:50). This section designation, as proposed in the work of Raymond Brown in his commentary on the Fourth Gospel (John I-XII, p. cxxxviii), is a conscious rejection of Bultmann's Semeia Source theory (cf. Raymond E. Brown, The Gospel According to John I-XII, vol. 29 [New York, NY: Doubleday, 1966], p. xxxi-xxxii). Though a consensus has developed concerning the first portion of the Fourth Gospel, within Johannine scholarship there continues to be dispute about how to designate the remaining chapters of the Fourth Gospel. For instance, whereas Brown preferred to refer to the remaining chapters as the Book of Glory (13-20), with an epilogue (21), C.H. Dodd preferred to speak of the Book of the Passion (13-21), which included two resurrection accounts (20-21) (Charles H. Dodd, The Interpretation of the Fourth Gospel [Cambridge, UK: Cambridge University Press, 1965], p. 289). In any case, however one divides the overall structure of the Fourth Gospel, the explicit references to the Old Testament in the Fourth Gospel can be neatly divided between language that speaks of Scripture as it is written during Jesus's public ministry $(2: 17 ; 6: 31$, $45 ; 8: 17 ; 10: 34 ; 12: 14)$, and Scripture as it is fulfilled after Jesus has withdrawn from public ministry $(12: 38 ; 13: 18$; $15: 25 ; 19: 24,36)$. This change in language from one narrative section to the next may well indicate a shift in how Old Testament intertextuality functions from one part of the Fourth Gospel to the next. The present study will focus on the first portion of the Fourth Gospel, and leave analysis of intertextuality in the later portion of the Fourth Gospel for other studies.
} 


\section{PAGE: THE TESTIMONY OF MOSES IN THE FOURTH GOSPEL}

Even beyond the Fourth Gospel's unique use of literary imagery, the idiomatic and thematic preferences of the Fourth Gospel, revealed in contrasts between 'light' and 'darkness,' 'truth' and 'lies,' even in the stance towards the 'world,' all these stylistic preferences can be experienced at the level of word choice. This distinctiveness in language is noteworthy. That the Fourth Gospel's composition postdates both the Pauline and Synoptic corpora, yet makes use of such a unique idiom, is remarkable. Why not adopt the manner and style of these well-established traditions when communicating the Christian message? Would not adopting these reputable and more widely recognized styles have lent the work an air of legitimacy? Apparently this was not a concern for the writer of the Fourth Gospel. Appreciating the intent behind this distinctive idiom is one of the most important elements to keep in mind when approaching the Fourth Gospel.

With the Fourth Gospel's unique literary preference when employing Old Testament intertextuality in mind, the next section of this paper will highlight some of the ways in which the framing of the Eucharistic Discourse in the Fourth Gospel differs from the framing of the eucharistic encounter in the Synoptic accounts, explore the meanings that appear to emerge from this distinctive framework, and conclude by proposing ways in which this framework invites Catholics to hearken to the voice of critique in inter-religious dialogue.

\section{Narrative in the Eucharistic Discourse: Into the Wilderness}

Whereas the Synoptics situate the eucharistic encounter at the outset of the Passion narrative, ${ }^{14}$ directly before Jesus's crucifixion and death, the Fourth Gospel places its eucharistic encounter at the very heart of Jesus's ministry, at the center of what is classically called the Book of Signs, the first twelve chapters of the Fourth Gospel. ${ }^{15}$ This Synoptic framing of the eucharistic

\footnotetext{
${ }^{14}$ Mt 26:26-29; Mk 14:22-25; Lk 22:15-20.

15 Jn $1: 19-12: 50$.
} 


\section{PAGE: THE TESTIMONY OF MOSES IN THE FOURTH GOSPEL}

encounter with the passion and crucifixion is made explicit in Luke: "I have eagerly desired to eat this Passover with you before I suffer..." (Lk 22:15) Both Matthew and Mark also include a note of finality in this eucharistic encounter, when Jesus reveals: "I tell you, I will never again drink of this fruit of the vine until that day when I drink it new in the kingdom of God." 16 With the Synoptic references to Jesus's blood being 'poured out for many, ${ }^{17}$ the link to the Passion is only further reinforced. ${ }^{18}$ Even prior to the Synoptic framing, Saint Paul of Tarsus states in his first epistle to the Corinthians that the passion and crucifixion of Jesus is at the heart of the Eucharistic encounter: "As often as you eat this bread and drink this cup, you proclaim the Lord's death until he comes."19

Now, given such an intimate connection being made between the Eucharist and the death of Jesus, it is at least conceivable that some misconceptions could have arisen. Is the Eucharist so tied to the death of Jesus that it has no bearing on his life, on his ministry? Does the meaning or significance of Jesus's death eclipse any fruit that may be drawn from his life in reference to the Eucharist? Moreover, if the symbolism of the Eucharist is so attached to the Passover, which is clearly the case in the Synoptics, then should the Eucharist likewise only be celebrated once a year, just as Passover is only celebrated once a year? On reading the Fourth Gospel's Eucharistic Discourse, the reader could well be forgiven for having the sense that many of these concerns appear to be directly addressed in the narrative. In the Fourth Gospel, the eucharistic encounter is located in the middle of Jesus's ministry, well within the purview of his daily life. Furthermore, the eucharistic encounter is not framed as a sacrifice, as an image of Jesus's death, but as an image of Jesus's life, with Jesus at one point in the discourse stating outright: "I am the bread of life"

${ }^{16}$ Mk 14:25; Mt 26:29; cf. Lk 22:16.

${ }^{17}$ Mt 26:28; Mk 14:24

${ }^{18}$ Though, arguably the spilling of blood is only concretely stated in the Fourth Gospel: "One of the soldiers pierced his side with a spear, and at once blood and water came out" (Jn 19:34).

191 Cor 11:26. 


\section{PAGE: THE TESTIMONY OF MOSES IN THE FOURTH GOSPEL}

(6:48). And rather than linking the Eucharist to the Passover meal, the Fourth Gospel frames the eucharistic encounter with the story of the Hebrews being fed manna in the wilderness. Jesus himself makes explicit reference to the manna, tying himself to that image: "The bread of God is that which comes down from heaven and gives Life to the world," 20 echoing the incarnational language from the Prologue (Jn 1:1-18), of the Word coming down from heaven and into the world.

There are, however, more proximate framing devices that the Fourth Gospel employs to draw out the wilderness context in the Eucharistic Discourse. The chapter in which the Eucharistic Discourse is located begins with two narratives that are also found in the Synoptics: the feeding of the multitudes (Mt 14:13-21; 15:32-39; Mk 6:30-44; Mk 8:1-10; Lk 9:10-17) and the walking on water (Mt 14:22-33; Mk 6:45-52). ${ }^{21}$ Following these parallels to the Synoptic account, the Fourth Gospel delivers the Eucharistic Discourse (6:25-71). Within the Eucharistic Discourse are significant echoes to the life of Moses during the wilderness journey, perhaps most notably: just as those who followed Moses were recalcitrant and hard-hearted, 'grumbling' against Moses's authority in the wilderness, so now the multitudes following Jesus are portrayed in much the same light, as the crowds 'grumble' ( $\gamma о \gamma \gamma v ́ \zeta \omega)$ against Jesus throughout the discourse $(6: 41,43,61)$.

This rather strange verb, 'grumble,' is noteworthy for reasons beyond its mere repetition. By deploying this particular verb within this particular setting, the Fourth Gospel is here echoing

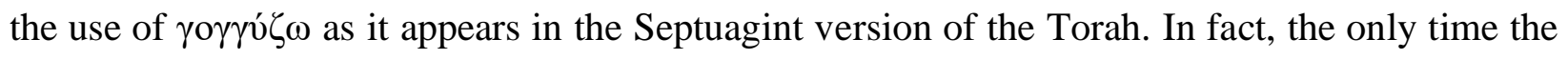
verb 'grumble' is ever used in Torah, it is used to describe the attitude of the people who followed

20 Jn 6:33.

${ }^{21}$ Interestingly, the feeding of the multitudes and the walking on water pericopes are told in precisely the same order, and directly follow one another, in two of the Synoptics, Matthew and Mark, as well as in the Fourth Gospel. In Mark, the feeding of the multitude (Mk 6:30-44) is directly followed by the walking on water pericope (Mk 6:45-52), as is the case in both Matthew (Mt 14:13-21, followed by Mt 14:22-33) and the Fourth Gospel (Jn 6:1-15, followed by 6:16-21). 


\section{PAGE: THE TESTIMONY OF MOSES IN THE FOURTH GOSPEL}

Moses in the wilderness: they 'grumbled' against Moses and against the Lord. ${ }^{22}$ The same Greek verb is found in both this Eucharistic Discourse from the Fourth Gospel and the Torah. This echo of the grumbling crowds from Numbers makes the reader immediately aware of the stakes: just as the lives of those who followed Moses ended in death because of their unwillingness to accept divine authority, so now the unwillingness to accept the authority of Jesus will end in death. For those who grumbled against Moses and divine authority, it was their unwillingness to heed the Divine that cut them off from that life-giving source in the wilderness: this grumbling in the Fourth Gospel is precisely what will cut the multitudes off from receiving the life offered by Jesus. The rhetorical effect is clear: if only the people had accepted the authority of Moses, they would have lived. Correspondingly, this passage from the Fourth Gospel is intended to lead the reader to accept the authority of Jesus, so as to share in Jesus's promise of eternal life..$^{23}$

As is its wont, the Fourth Gospel sets up a literary echo, weaving the wilderness journey of the ancestors into this dialogue between Jesus and the multitudes. This is not Passover imagery; the Fourth Gospel is employing wilderness imagery. The manna was daily delivered to the children of Israel, to sustain them in the wilderness. ${ }^{24}$ By referencing the manna, then, the Fourth Gospel does not frame its eucharistic encounter with a ritual like the Passover that was performed annually, but to a meal that was eaten daily. To make the point in terms of directionality, in terms of the

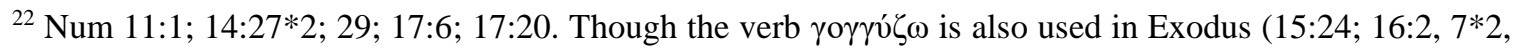
$8 * 3,9,12 ; 17: 3$ ), likewise describing the people grumbling against Moses, there is a very good reason to discount this ostensible connection to the narrative found in Exodus. Later on in the discourse, Jesus will claim: "Your ancestors ate the manna in the wilderness, and they died" (Jn 6:49). This connection between the consumption of manna and the death of the ancestors occurs in the Numbers narrative: cf. Num 11:4-9; 14:26-30. This same connection between the consumption of manna and the death of the ancestors is not made in the Exodus narrative. It appears as though the only people who die following Moses in the wilderness during the Exodus narrative were those involved in the Golden Calf incident, and the story of the Golden Calf has nothing to do with manna (cf. Exodus 32:25-28).

${ }^{23}$ This intention on the part of the Fourth Gospel will be made explicit later on: "These are written so that you may come to believe that Jesus is the Messiah, the Son of God, and that through believing you may have life in his name" (20:31).

${ }^{24}$ Though, just to be clear, there is a tradition claiming that every sixth day the Hebrews would gather two days' worth of manna, so that they would not break the Sabbath (cf. Exodus 16:22ff). 


\section{PAGE: THE TESTIMONY OF MOSES IN THE FOURTH GOSPEL}

origin and direction of action, we could almost say that the Fourth Gospel is trying to make the opposite point in this eucharistic encounter. The Old Testament image used to frame the Synoptic accounts of the Eucharist is the Passover, and at the center of the Passover is the Passover lamb. The Passover lamb is brought by the people, and is slaughtered by the people, in order to protect them from the wrath of the tenth plague, to propitiate the Divine. The manna in the wilderness, by contrast, is provided by God, and supplied by God daily during the wilderness journey, in order to sustain those who journeyed through the wilderness. In the Fourth Gospel's Eucharistic Discourse, Jesus is not framed as some offering that the people bring to propitiate the Divine, but as a gift from the Divine to the people, to give Life to the world, to bring Life into the world. Rather than any reliance on sacrificial or Passover imagery in this passage, the Fourth Gospel portrays Jesus as true food from the Divine, and as the one who sustains us in the wilderness.

Whether the evangelist placed the Eucharistic encounter towards the end of the Gospel or towards the middle of the Gospel, alongside Jesus's death or in the midst of Jesus's life, makes a difference. Whether the evangelist framed the Eucharist as a memorial of Christ's death, or as a witness to Christ's life, makes a difference. Whether the evangelist framed the Eucharistic encounter with the Passover lamb or with the manna, as a human offering to the Divine or as a Divine offering to humanity, makes a difference. But there is one last distinction between the Synoptic accounts and the Johannine account that bears review, in how blood imagery is used, and it is here where Catholics should be willing to be challenged.

\section{A Hard Teaching: Drinking the Blood of Jesus from the Torah Prohibitions}

The broader implications of the Eucharistic Discourse, itself is a significant turning point in the Fourth Gospel, are received within a unique framework of Old Testament intertextuality. 


\section{PAGE: THE TESTIMONY OF MOSES IN THE FOURTH GOSPEL}

Even those passages that appear to most closely parallel one another across the New Testament accounts of the Eucharist should be reexamined. For instance, the ostensibly close linguistic parallel between the Fourth Gospel's depiction of Jesus with the phrase 'my flesh, for the life of the world, ${ }^{25}$ and the Pauline eucharistic formula 'my body, for you, ${ }^{26}$ can obscure one obvious distinction: in the Fourth Gospel, the very purpose of the flesh of the Son of Man is that it brings Life, not that it is being handed over to death 'on behalf of' another. ${ }^{27}$ The language that Jesus uses in the Eucharistic Discourse to describe the sustenance that he brings develops incrementally. Jesus identifies himself with 'the bread of life' $(6: 35,38,41)$, ultimately resorting to more explicitly incarnational imagery when describing the eucharistic encounter: 'This is the bread that comes down from heaven' $(6: 50,51,58)$, much as Jesus himself has come down from heaven (6:38), from where he was 'before' (6:62). Yet it is towards the end of the discourse that the Fourth Gospel depicts Jesus as making this most contentious claim, where Jesus states: “Amen, amen, I tell you, unless you eat the flesh of the Son of Man and drink his blood, you have no life in you" (6:53).

Now, blood language and rhetoric appear in both the Fourth Gospel and the Synoptics in connection with the Eucharist. However, the manner in which this rhetoric is deployed could not be more different. Though the Institution narratives in the Synoptics have Jesus proclaiming the elements as his body and blood, the blood is immediately framed in covenantal and sacrificial

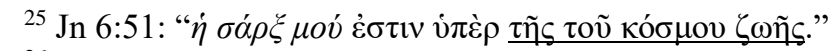

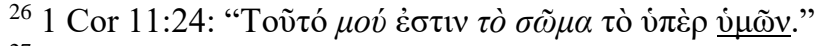

${ }^{27}$ This actually boils down to what can appear to be a rather nuanced distinction in the prepositional use of

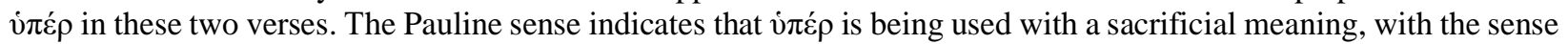
of his body being given 'on behalf of' the other (1 Cor 11:24), much the same way vixe is used in other parts of

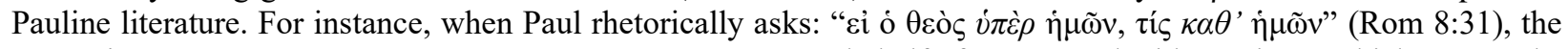
use of $\dot{\tau} \pi \dot{\varepsilon} \rho$ is being contrasted with the preposition $\kappa \alpha \tau \alpha$, 'on behalf of' contrasted with 'against,' which gets us the translation: "If God [acts] on our behalf, who is against us?" Paul follows this rhetorical question by pointing out how God has acted on our behalf (cf. Rom 8:32). This use of vं $\pi \dot{\varepsilon} \rho$ in Paul should be distinguished from the Johannine use of vi $\varepsilon_{\rho} \rho$ in the Eucharistic Discourse. In the Fourth Gospel, Jesus does not claim that he is giving his flesh 'on behalf of' the life of the world (cf. 6:51). The Eucharistic Discourse makes it clear that Jesus is not giving his flesh away to someone else 'on behalf of' the life of humanity, in some kind of sacrificial dynamic. Rather, it is that his flesh and blood, in this eucharistic encounter, is the very thing that brings Life to the world (cf. 6:27, 33, 35, 48). 


\section{PAGE: THE TESTIMONY OF MOSES IN THE FOURTH GOSPEL}

language: "This is my blood of the covenant, which is poured out for many." ${ }^{28}$ Given that the Synoptics frame the eucharistic encounter with the Passover, the rhetoric of blood use could be seen as making reference to the blood of the Passover lamb, or alternatively to the sacrificial blood used to seal a covenant. Both of these are perfectly understandable frameworks for blood use in the Old Testament, whether the blood is used to paint the lintels of the doors, or sprinkled on the altar in sacrifice. However, and this is important, neither of these Old Testament frameworks are about blood consumption. The Old Testament framework in the Synoptics are about uses of blood consonant with Jewish tradition.

Notice how in the Synoptics and Paul, the eucharistic wine signifies 'the blood of the covenant. ${ }^{29}$ This identification is important, because the blood offered in sacrifice was used to seal the covenant according to the Old Testament paradigm. ${ }^{30}$ In the Fourth Gospel's Eucharistic Discourse, however, no mention of covenant is made whatsoever. Indeed, in the Eucharistic Discourse, it is not a covenant that is sealed, but the Son of Man, and it is not the community who seals him, but the Father in heaven: "Do not work for the food that perishes, but for the food that endures for eternal life, which the Son of Man will give you. For it is on him that God the Father has set his seal" (6:27). The framework is no longer of the community's sacrifice sealing a covenant with the Divine, but of the Divine sealing his own offering to humanity.

If the Fourth Gospel uses neither Passover nor sacrificial imagery in its framing of the Eucharistic Discourse, then it appears incumbent on the Church to encounter these words in a challenging new way: "Amen, amen, I tell you, unless you eat the flesh of the Son of Man and

${ }^{28}$ Mk 14:24; cf. Mt 26:28; Lk 22:20.

${ }^{29}$ Mk 14:24; Mt 26:28; Lk 22:20; 1 Cor 11:25.

30 Though, to be sure, this connection between the shedding of blood and the sealing of a covenant is echoed in New Testament texts, as well (cf. Heb 9:18-22). 


\section{PAGE: THE TESTIMONY OF MOSES IN THE FOURTH GOSPEL}

drink his blood, you have no life in you" (Jn 6:53). Again, in the next verse, Jesus tells the multitudes to "drink my blood" (6:54). Yet again, in the following verse, he tells the multitudes that "my blood is true drink" (6:55). And finally, as though his point was not clear enough, he ends with: "drink my blood" (6:56). Four times, in as many verses, Jesus reiterates that his blood is to be consumed. And moreover, that one's salvation is tied to the consumption of his blood. Why do the Jewish multitudes abandon Jesus after this 'hard teaching'? The consumption of blood is one of the most often repeated prohibitions in Torah (second only to the commandments against idolatry), and one with severe consequences for the one violating it. The first time that the Torah reveals the prohibition on consuming blood is towards the end of the Flood Narrative (Gen 6:59:19). Even before the injunction against murder, God commands those who survived the Flood: "You shall not eat flesh with its life, that is, its blood" (Gen 9:4). In fact, every single time the prohibition against the consumption of blood is delivered in Torah, it is delivered directly from the mouth of God. So, coming back to the Fourth Gospel, why has the evangelist depicted Jesus using language that, on the face of it, appears to directly conflict with this extremely important Torah commandment, one repeatedly delivered from the mouth of God?

One of the more shocking things one encounters when seeking to confront this difficult passage of Scripture is just how silent the commentary tradition is on this particular problem. Justin Martyr in his tract on the Eucharist, ${ }^{31}$ Origen of Alexandria in his homilies on Leviticus and John, ${ }^{32}$

${ }^{31}$ Here I am referencing Justin Martyr's chapter on the Eucharist in his First Apology: Justin Martyr, "The First Apology of Justin," in The Apostolic Fathers with Justin Martyr and Irenaeus, eds. Alexander Roberts, James Donaldson, and A. Cleveland Coxe (Buffalo, NY: Christian Literature Company, 1885), p. 185.

${ }^{32}$ Origen Adamantius, Origen: Homilies on Leviticus, trans. Gary W. Barkley (Washington, DC: Catholic University of America Press, 1990); Commentary on the Gospel According to John, Books 1-10, trans. Ronald E. Heine (Washington, DC: Catholic University of America Press, 1989). 


\section{PAGE: THE TESTIMONY OF MOSES IN THE FOURTH GOSPEL}

Augustine's tractates on John, ${ }^{33}$ Chrysostom's homilies on John, ${ }^{34}$ Aquinas's commentary on John, ${ }^{35}$ not one of them raises this issue. According to traditional commentaries, there is no problem with the rhetoric that Jesus deploys in this passage. The problem, if there is any, rests with the Jewish interlocutors, who are often depicted as having a 'disordered attachment' to Moses. However, this traditional interpretation cuts against the grain of the Fourth Gospel itself. Repeatedly, Jesus argues for his continuity with Moses, admitting: "If you trusted in Moses, you would trust in me, for he wrote about me" (Jn 5:46). In the Fourth Gospel, Jesus does not exhort the people to abandon Moses; rather, he repeatedly admits that his teachings rely on the testimony of Moses.

Reconciling the use of blood consumption language in the eucharistic encounter with the Torah prohibitions on the consumption of blood begins by understanding the intent of the Torah laws on purity of substance. The text of Scripture makes clear that within the metaphysical framework of the Old Testament, "the life of every creature is its blood" (Lev 17:14). ${ }^{36}$ If the life of every creature is its blood, then by drinking the blood of another creature, one is commingling one's life essence with that of another. By drinking the blood of an animal, the person is effectively corrupting his or her essence, made as it is in the image of God, with that of an animal. This intermingling of life would have struck Jews as particularly offensive, because as is readily

\footnotetext{
${ }_{33}^{33}$ Aurelius Augustine, Tractates on the Gospel of John, 11-27, trans. John W. Rettig (Washington, DC: The Catholic University of America Press, 1988).

${ }^{34}$ John Chrysostom, Commentary on Saint John the Apostle and Evangelist, Homilies 1-47, trans. Sister Thomas Aquinas Goggin, The Fathers of the Church Series, vol. 33 (Washington, DC: The Catholic University of America Press, 1969).

${ }^{35}$ Thomas Aquinas, Commentary on the Gospel of John, Chapters 6-12, trans. Fabian Larcher and James A. Weisheipl (Washington, DC: Catholic University of America Press, 2010).

${ }^{36}$ cf. Deut 12:23.
} 


\section{PAGE: THE TESTIMONY OF MOSES IN THE FOURTH GOSPEL}

apparent after reading the juridical section of the Torah, there are numerous and varied laws that proscribe the Jewish people from intermingling across a number of dimensions. ${ }^{37}$

For instance, across the zoological dimension, Jews are prohibited from intermingling species of animals, breeding one kind with another. ${ }^{38}$ Within the agricultural dimension, Torah prohibits sowing a field with two distinct kinds of seeds, ${ }^{39}$ nor are Jews allowed to plow a field with two different kinds of animals. ${ }^{40}$ This prohibition on intermingling extends even to how one should dress, as Torah prohibits the Jew from wearing clothes woven of two different kinds of fabric. ${ }^{41}$ Given the numerous prohibitions on intermingling throughout Torah, the consumption of blood can be properly understood as the most offensive violation of this general principle. ${ }^{42}$ If these other instances of intermingling are prohibited, and they only relate to external, worldly

${ }^{37}$ Intermingling as a concept in Jewish purity is attested to not only from these biblical sources, but is a continuing source of reflection in Jewish communities in the Second Temple Period, and features prominently in the writings of the Dead Sea Scrolls: "These are some of our pronouncements concerning the Law of God; specifically, some of the pronouncements concerning works of the Law which we have determined ... and all of them concern defiling mixtures" (4Q394 frag. 3 col. i:1-2; cf. 4Q396 frag. 1-2 col. iv:76-77a [against interbreeding animals], 77b78a [against wearing a garment of mixed fabric], 78b [against sowing a field with two kinds of plants], 79-81 [against mixing the holy 'seed' of Israel with foreign wives]). Indeed, when the Divine is casting a spirit of confusion upon

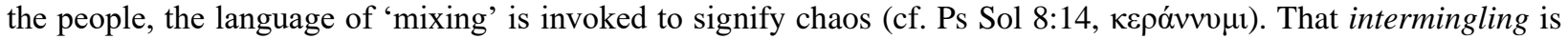
cast in a negative light is no great surprise, since 'holiness' is often cast in converse terms, as denoting a kind of separation (cf. David A. deSilva, "Holy and Holiness, Clean and Unclean," in Dictionary of the Old Testament: Pentateuch, eds. T. Desmond Alexander and David W. Baker [Downers Grove, IL: IVP Academic, 2003], pp. 420431). For a more extended treatment on the manner in which purity regulations were received during the Second Temple Period: Hannah K. Harrington, "Interpreting Leviticus in the Second Temple Period: Struggling with Ambiguity," in Reading Leviticus: A Conversation with Mary Douglas, ed. John F.A. Sawyer (Sheffield, UK: Sheffield Academic Press, 1996), pp. 214-229.

${ }^{38}$ Lev 19:19.

${ }^{39}$ Lev 19:19; Deut 22:9.

${ }^{40}$ Deut 22:10.

${ }^{41}$ Lev 19:19; Deut 22:11.

${ }^{42}$ Another promising interpretation of the prohibition on consuming meat with blood notes that the offense may well have been elicited by the unnatural mixture of life (blood) and death (flesh) in the very same substance that one consumes: "You must not consume the life with the flesh" (Deut 12:23b). For instance, when we bring the taboo on intermingling to the law against cooking a kid in its mother's milk (Exod 23:19), we note the unnatural mixture of "cooking the dead kid in the very milk that was its life and sustenance... The dead animal and the blood do not go together, just as the dead kid and the milk do not" (Calum M. Carmichael, The Laws of Deuteronomy [Ithaca, NY: Cornell University Press, 1974], pp. 152-153). This intermingling taboo, against the mixing of different kinds, extends beyond the features of one's daily life, and even offers an explanation for the horror that would be felt from the sin of the celestial beings having intercourse with humans (cf. Gen 6:1-5). In 1 Enoch the angelic beings are addressed by the Divine: "You were holy ones and spirits, living forever," yet they had intercourse with human beings, "who die and perish" (1 Enoch 15:4), thus another unnatural mixture of kinds. 


\section{PAGE: THE TESTIMONY OF MOSES IN THE FOURTH GOSPEL}

matters, how one dresses, or how one plows a field, then certainly an act that violates the integrity of the self, intermingling one's life with the life of an animal, would be that much more of a violation.

\section{Union with the Divine: The Eucharistic Encounter}

However, that the consumption of blood intermingles the essence and life of two beings is the very reason Jesus commands the multitudes to drink his blood, using this language of blood consumption. Within the Fourth Gospel, Jesus is depicted as having eternal life, indeed of being eternal life. ${ }^{43}$ The language and rhetoric that Jesus uses in this instance, of exhorting the multitudes to eat his flesh and drink his blood, makes perfect sense within this framework. With the metaphysical framework of the Old Testament, in order for the Eucharistic encounter to fully unite humanity with the Divine, the multitudes must drink the blood of Jesus, the blood wherein his life can be shared. By doing so, the life of the Divine in Jesus is intermingled with their own humanity, granting them life eternal. ${ }^{44}$ With this understanding in mind, Jesus's claims of his life being imparted through the consumption of his flesh and blood make far more sense. When the Fourth Gospel has Jesus proclaim that without eating his flesh and drinking his blood "you have no life in yourselves" (v. 53):

Jesus assumes the simple equation of blood with life, and 'life in yourselves' expresses in frank terms the logical result of the ingestion of that which represents life, i.e. blood. Flesh without blood is void of life; for the flesh-bread everlasting."

${ }^{43}$ Jn 1:1-4, 14; 4:14; 6:27; cf. Augustine, John, p. 267: "For Christ himself is the true God and life

${ }^{44}$ Credit for this argument goes to Steven Bridge, who laid out its main structure in his short introduction to Gospel literature: cf. Steven L. Bridge, "Jesus' Teachings: The Bread of Life Discourse," in Getting the Gospels: Understanding the New Testament Accounts of Jesus' Life, chpt. 6 (Grand Rapids, MI: Baker Academic, 2004). Though van Noppen casts this tension rather more starkly than perhaps I would, it is eloquently expressed nonetheless: "Jesus' requirement that his followers eat his flesh with the blood embodies the 'spirit and truth' of the blood

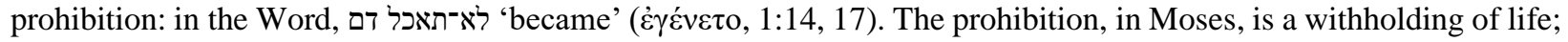
in Christ it is its grant" (Roland van Noppen, Drinking the Blood of Jesus: A Theological Rationale from the Jewish Blood Prohibitions [Lewiston, NY: Edwin Mellen Press, 2015], p. 330). 


\section{PAGE: THE TESTIMONY OF MOSES IN THE FOURTH GOSPEL}

of the Son of Man to communicate life, it must do so by virtue of its life/blood. Hence, blood is added to flesh as a prerequisite to having life in oneself. ${ }^{45}$

In commanding the multitudes to drink his blood, Jesus is not violating the Torah, but fulfilling its intent: "You shall be holy, for I the LoRD your God am holy" (Lev 19:2; cf. 1 Peter 1:15-16). The whole of Torah is to sanctify a people for God, to make a holy people, just as the Lord our God is holy. And in order to be holy just as the Lord our God is holy, intermingling humanity's life with Jesus's, Divine Union, is precisely what brings the Church into this eternal life. Intermingling one's life essence with Jesus is the sine qua non for one's eternal salvation. ${ }^{46}$

\section{Concluding Remarks: Jewish and Catholic Dialogue}

\footnotetext{
${ }^{45}$ van Noppen, Theological Rationale, p. 324.

${ }^{46}$ Though I agree with the work of Pitre, inasmuch as I concur that the reason Jesus uses this language of blood consumption has to do with the identification of life with the blood, I would want to qualify one aspect of Pitre's argument from Leviticus: "In the passage from Leviticus above, notice that the reason given for abstaining from animal blood is that 'the life is in the blood,' and the blood is given by God 'to make atonement for your souls"' (cf. Brandt Pitre, Jesus and the Jewish Roots of the Eucharist: Unlocking the Secrets of the Last Supper [New York, NY: Image, 2015], pp. 109). The passage from Leviticus that Pitre references reads: "For the life of the flesh is in the blood; and I have given it to you for making atonement for your lives on the altar; for, as life, it is the blood that makes atonement" (Lev 17:10). This passage from Leviticus refers to the Holiness Code regulation that required all slaughtered animals be brought to the altar to have their blood drained. When shrines were allowed throughout the land, local altars could be used to satisfy this requirement. However, with the centralization of the cult in Jerusalem this practice was abrogated, likely because of the difficulties involved in implementing such a regulation across an entire nation with just a single Temple. Despite the persistence of ritual elements in the slaughter of animals (the draining of blood), later texts will purposely empty these practices of sacrificial content, such that blood no longer needed to be reserved for the altar, but could be poured out on any ground, "like water" (cf. Deut 12:16): "This pouring out of the blood is definitely denied the character of a sacrifice (it is to be like water)" (Gerhard von Rad, Deuteronomy: A Commentary, trans. Dorothea Barton [Philadelphia, PN: The Westminster Press, 1966], p. 93). Note that since Deuteronomy claims that the blood is to be treated 'like water' (כמים), the poured-out blood no longer needs to be covered by dirt in order to avoid blood-guilt (cf. Lev 17:13). This Deuteronomic tradition effectively abrogates the Priestly stricture (or, more precisely, the Holiness Code regulation) that all blood must be reserved for the altar. As Tigay points out, the passing away of this Holiness Code regulation made a certain degree of sociological sense: "This rule was practical when all Israelites lived near a sanctuary, as when they lived in the wilderness. Even after they settled in Canaan and scattered across the land, it would remain practical as long as it was legitimate to have sanctuaries throughout the land. But once a single sanctuary was chosen, the requirement would become impractical..." (Jeffery H. Tigay, The JPS Torah Commentary: Deuteronomy [Philadelphia, PA: The Jewish Publication Society, 1996], p. 124) It should be noted that the Temple Scroll, however, sides with Leviticus, commanding that: "You must not slaughter any clean ox, sheep, or goat in any of your towns within a three-day journey of My temple. Instead you must sacrifice it in My temple, making of it a burnt offering or a peace offering. Then you shall eat and rejoice before Me in the place that I will choose to establish My name" (11QT 52:13-16). A radius of a three-day's journey from the Temple effectively includes most of Israel. In any case, in this present work I have highlighted the non-sacrificial elements in the framing of the Eucharistic Discourse, specifically, the Old Testament narrative framework of the journey through the wilderness wherein the ancestors were fed manna by the Divine. I do not see sacrificial regulations as readily explanatory within this particular framework.
} 


\section{PAGE: THE TESTIMONY OF MOSES IN THE FOURTH GOSPEL}

The celebration of the Eucharist, of giving thanks for the saving mystery of Christ in their lives, has been a Christian tradition since the earliest times of the Church. ${ }^{47}$ However, the Fourth Gospel expands the Synoptic narrative framework of an intimate meal between Jesus and the Twelve, to encompass the entirety of the world. The Fourth Gospel makes clear that it is those who have faith in Jesus (6:47) and discern his divinity (6:67-69), who can receive this eucharistic encounter. In the Fourth Gospel, the Eucharist is not framed as a meal shared amongst apostles, but as a life-giving blessing bestowed upon all of humanity. Refusing to hearken to the genuine and legitimate concerns of the Jewish interlocutors in the Fourth Gospel has not only denied the voice of Judaism a space for dialogue with the Catholic Church, but it appears to have obscured an amazing opportunity to recover a more authentic manner of being-in-the-world. ${ }^{48}$

The history of using the Scriptures to silence and censure Jewish interlocutors is well documented, as is the history of interpreting the Fourth Gospel to advance anti-Jewish claims. ${ }^{49}$ The response of excising the anti-Jewish underpinnings within Catholic theology is not simply an intellectual exercise, but is an integral part of what we as a Church are called to do and be in Nostra aetate: "Since the spiritual patrimony common to Christians and Jews is thus so great, this sacred synod wants to foster and recommend mutual understanding and respect, which is the fruit, above all, of biblical and theological studies, as well as of fraternal dialogues." ${ }^{50}$ How can we engage in fraternal dialogue if we obfuscate the genuine concerns of our dialogue partners?

\footnotetext{
${ }^{47}$ As evidenced by the Institution Narrative within 1 Corinthians, demonstrating that even before the gospels had been written, the Eucharist was a part of Christian life (1 Cor 11:23-26; cf. Acts 2:42).

${ }^{48}$ Apologies: I have spent too much time around phenomenologists!

${ }^{49}$ For an absolutely fantastic book, covering a number of a viewpoints on the potential dangers of antiJudaism in the Fourth Gospel, see: Reimund Bieringer, Didier Pollefeyt, Frederique Vandecasteele-Vanneuville, eds., Anti-Judaism and the Fourth Gospel (Louisville, KY: Westminster John Knox Press, 2001).

${ }^{50}$ Pope Paul VI, Nostra aetate: Declaration on the Relation of the Church to non-Christian Religions (Vatican City, Rome: October 28, 1965), n. 4.
} 


\section{PAGE: THE TESTIMONY OF MOSES IN THE FOURTH GOSPEL}

The tension in the Eucharistic Discourse, then, is not between those who have a disordered attachment to Moses and those who have received Christ's Gospel of grace, as though the testimony of Moses were in opposition to Christ and his Gospel. Rather, receiving Jesus's teaching from the Eucharistic Discourse is only possible for those who have already discerned the divine origin of the Son of Man, of Jesus Christ. Discerning the true nature of the Christ is principally what the signs of the Fourth Gospel are intended to reveal. Indeed, the communal dimension of this divine recognition is inscribed within the Fourth Gospel itself, where Jesus's glory is only witnessed by those who believe (2:11; cf. 11:40). The Fourth Gospel, in its own prologue, frames the incarnation of the Word and the revelation of Christ as a communal witness to Jesus's glory and divinity, with the words: "we have seen his glory" (cf. 1:14). The instruction imparted through the Fourth Gospel, and in the Eucharistic Discourse in particular, of Christ's life-giving reality in the eucharistic encounter, could only be received by the one who already believes: "But these are written so that you may come to believe that Jesus is the Messiah, the Son of God, and that through believing you may have life in his name" (20:31).

It is this discernment of Christ's divinity and origin, then, that distinguishes the person who receives this teaching from the one who would reject it. Jesus's words definitively convince the multitudes to abandon him because they do not discern his divinity. Why would someone accept this hard teaching, with its language and rhetoric, when the teaching would only make sense if the one delivering it were divine? It is at the conclusion of the discourse, when Jesus asks the Twelve whether they too want to leave, that Peter's response confirms their belief in his divinity: "We have come to know that you are the Holy One of God" (6:69). By the words of the Twelve, the reader can see that the only reason they are able to accept and receive this teaching is because they discern his divinity. 


\section{PAGE: THE TESTIMONY OF MOSES IN THE FOURTH GOSPEL}

The careful use of Old Testament intertextuality, the repeated insistence on the testimony of Moses as legitimizing Jesus's ministry, makes it clear that the Fourth Gospel intends to operate within a framework of continuity with a tradition of Jewish thought that would not have functioned by violating Torah. Jesus's challenging command to 'drink my blood,' when understood in light of the intent of the Old Testament proscriptions on the consumption of blood, makes it clear that far from violating Torah, the Fourth Gospel intends Jesus to fulfill the Torah. No longer should our exegesis of this passage rely on anti-Jewish portrayals of the multitudes as 'carnal,' or 'clinging' to an outdated Mosaic Law. In fact, the Torah that came through Moses (1:17a) is not what would hold someone back from appreciating the eucharistic significance of these verses, but is precisely that which would lead one to understand them as such (1:17b): “Amen, amen, I tell you, unless you eat the flesh of the Son of Man and drink his blood, you have no life in you" (6:53). Suppressing this deliberate tension in the narrative misses one of the strongest foundations for eucharistic theology, grounded as it is in continuity with Old Testament. 


\section{PAGE: THE TESTIMONY OF MOSES IN THE FOURTH GOSPEL}

\section{Table 1: Lexical Frequency List of the Gospels ${ }^{51}$}

\begin{tabular}{l|cccc}
\multicolumn{1}{c}{} & Fourth Gospel & Matthew & Mark & Luke \\
\hline believe & 98 & 11 & 14 & 9 \\
world & 78 & 8 & 3 & 3 \\
love & 57 & 17 & 9 & 18 \\
know & 141 & 44 & 33 & 53 \\
truly & 50 & 31 & 14 & 6 \\
life & 36 & 7 & 4 & 5 \\
truth & 55 & 6 & 6 & 8 \\
witness & 47 & 4 & 6 & 5 \\
ask & 28 & 4 & 3 & 15 \\
light & 23 & 7 & 1 & 7 \\
father & 136 & 63 & 18 & 56 \\
glory & 42 & 11 & 4 & 22 \\
remain & 40 & 3 & 2 & 7
\end{tabular}

${ }^{51}$ Tabulating the lexical frequency was done through Bibleworks 9 software: Bibleworks 9 Software for Biblical Exegesis \& Research (Norfolk, VA: Bibleworks, 2011).

52 The Fourth Gospel uses the word 'truly,' $\dot{\alpha} \mu \eta \eta v$, more than do the Synoptics, but not by an exceptionally large margin. What makes the Fourth Gospel's use of the word $\dot{\alpha} \mu \eta \dot{v}$ notable is that even though $\dot{\alpha} \mu \eta \dot{v} v$ is used in much

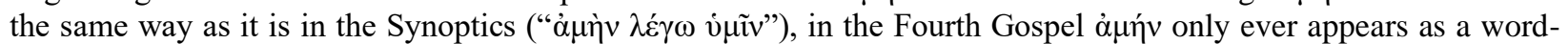
pair: "Truly, truly, I say to you all..." Both biblical (Num 5:22; Ps 41:13; 72:19; 89:52; Neh 8:6; Tob 8:8 [GII recension, Codex Sinaiticus]) and extra-biblical (1QS col. i:20; ii:10, 18; 4Q286 frag. 7 col. i:7; col. ii:1; 4Q287 col. i:1; 4Q289 frag. 1:2; frag. 2:4; 4Q504 col. vii:2 [?]; col vii:9 [?]; 4Q511 frag. 63 col. iv:2) sources attest to this practice of word-pairing $\dot{\alpha} \mu \eta \dot{v} v$. Admittedly, some of the purported instances of word-pairing אמן from the Dead Sea Scrolls are conjectural. Because the word-pairing of in the Dead Sea Scrolls is commonly associated with liturgical texts, some of the text fragments that cut off with only a single could well have been instances of word-pairing: "In the scrolls, the bifold 'Amen, Amen' is indicative of communal prayers" (Michael O. Wise, Martin G. Abegg, and Edward M. Cook, trans., The Dead Sea Scrolls: A New Translation [New York, NY: HarperOne, 2005], p. 207). Interestingly

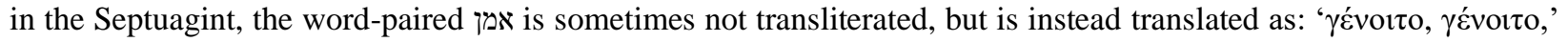
as in, 'may it be so, may it be so!' (cf. LXX Num 5:22; Ps 40:14; 71:19; 88:53; 105:48; Jdt 13:20).

${ }^{53}$ The word 'light,' $\varphi \tilde{\omega} \varsigma$, disappears after Jn 12:46, signaling the end of Jesus's public ministry. 


\section{PAGE: THE TESTIMONY OF MOSES IN THE FOURTH GOSPEL}

\section{Bibliography}

Ashton, John. "Intimations of Apocalyptic." In Understanding the Fourth Gospel, 383-406. Oxford, UK: Clarendon Press, 1991.

Augustine. Tractates on the Gospel of John, 11-27. Translated by John W. Rettig. Vol. 79. Washington, DC: The Catholic University of America, 1988.

Barrett, Charles K. "The Old Testament in the Fourth Gospel." The Journal of Theological Studies 48, no. 191/192 (October 1947): 155-69.

Bieringer, Reimund, Didier Pollefeyt, and Frederique Vandecasteele-Vanneuville, eds. AntiJudaism and the Fourth Gospel. Louisville, KY: Westminster John Knox Press, 2001.

Bridge, Steven L. “Jesus' Teachings: The Bread of Life Discourse." In Getting the Gospels: Understanding the New Testament Accounts of Jesus' Life, Chapter 6. Grand Rapids, MI: Baker Academic, 2004.

Brown, Raymond E. The Community of the Beloved Disciple. New York, NY: Paulist Press, 1979.

—. The Gospel According to John I-XII. New York, NY: Doubleday, 1966.

Bultmann, Rudolph K. The Gospel of John: A Commentary. Translated by George R. BeasleyMurray, Rupert W.N. Hoare, and John K. Riches. Philadelphia, PA: Westminster Press, 1971.

Carmichael, Calum M. The Laws of Deuteronomy. Ithaca, NY: Cornell University Press, 1974.

Charlesworth, James H. "Part One: Origin, Evolution, and Settings of the Gospel of John." In Jesus as Mirrored in John: The Genius of the New Testament, 19-127. New York, NY: T\&T Clark, 2019.

deSilva, David A. "Holy and Holiness, Clean and Unclean." In Dictionary of the Old Testament: Pentateuch, edited by T. Desmond Alexander and David W. Baker, 420-31. Downers Grove, IL: IVP Academic, 2003.

Dodd, Charles H. The Interpretation of the Fourth Gospel. Cambridge, UK: Cambridge University Press, 1965.

Harrington, Hannah K. "Interpreting Leviticus in the Second Temple Period: Struggling with Ambiguity." In Reading Leviticus: A Conversation with Mary Douglas, edited by John F.A. Sawyer, 214-29. Sheffield, UK: Sheffield Academic Press, 1996.

Hays, Richard B. Echoes of Scriptures in the Gospels. Waco, TX: Baylor University Press, 2016. 


\section{PAGE: THE TESTIMONY OF MOSES IN THE FOURTH GOSPEL}

John Chrysostom. Commentary on Saint John the Apostle and Evangelist, Homilies 1-47. Translated by Sr. Thomas Aquinas Goggin. Washington, DC: The Catholic University of America, 1969.

Justin Martyr. “The First Apology of Justin.” Edited by Alexander Roberts, James Donaldson, and A. Cleveland Coxe, 1:163-87. The Ante-Nicene Fathers. Buffalo, NY: Christian Literature Company, 1885.

Köstenberger, Andreas J. "John." In Commentary on the New Testament Use of the Old Testament, edited by Gregory K. Beale and Donald A. Carson, 415-512. Grand Rapids, MI: Baker Academic, 2007.

Kysar, Robert. "The Whence and Whither of the Johannine Community." In Life in Abundance: Studies in John's Gospel in Tribute to Raymond E. Brown, edited by John R. Donahue, 65-90. Collegeville, MN: Liturgical Press, 2005.

Menken, Maarten J.J. “Old Testament Quotations in the Gospel of John.” In New Testament Writers and the Old Testament, 29-45. London, UK: SPCK, 2002.

Murphy, Frederick J. “The Gospel of John.” In Apocalypticism in the Bible and Its World, 27578. Grand Rapids, MI: Baker Academic, 2012.

Noppen, Roland van. Drinking the Blood of Jesus: A Theological Rationale from the Jewish Blood Prohibitions. Lewiston, NY: Edwin Mellen Press, 2015.

Origen. Origen: Homilies on Leviticus. Translated by Gary W. Barkley. Washington, DC: The Catholic University of America, 1990.

Paul VI. Nostra Aetate: Declaration on the Relation of the Church to the Non-Christian Religions. Vatican City, 1965.

Pitre, Brant J. Jesus and the Jewish Roots of the Eucharist: Unlocking the Secrets of the Last Supper. New York, NY: Doubleday, 2015.

Thomas Aquinas. Commentary on the Gospel of John: Chapters 6-12. Translated by Fabian Larcher and James A. Weisheipl. Washington, DC: The Catholic University of America, 2010.

Tigay, Jeffery H. The JPS Torah Commentary: Deuteronomy. Philadelphia, PA: The Jewish Publication Society, 1996.

von Rad, Gerhard. Deuteronomy: A Commentary. Translated by Dorothea Barton. Philadelphia, PA: The Westminster Press, 1966. 


\section{PAGE: THE TESTIMONY OF MOSES IN THE FOURTH GOSPEL}

Westcott, Brooke F., and Fenton J.A. Hort. The New Testament in the Original Greek. London, UK: MacMillan Publishing Co., 1914.

Williams, Catrin H., and Christopher Rowland, eds. John's Gospel and Intimations of Apocalyptic. New York, NY: Bloomsbury T\&T Clark, 2013.

Wise, Michael O., Martin G. Abegg, and Edward M. Cook. The Dead Sea Scrolls: A New Translation. San Francisco, CA: HarperCollins, 2005. 